University of Nebraska - Lincoln

DigitalCommons@University of Nebraska - Lincoln

Mechanical \& Materials Engineering Faculty

Publications

Mechanical \& Materials Engineering

Department of

2011

\title{
It's Not What You Think: A Theory for Understanding the Lack of Interest among Domestic Students in the Engineering PhD
}

\author{
Michelle C. Howell Smith \\ University of Nebraska-Lincoln, mhowellsmith@unl.edu \\ Amanda L. Garrett \\ University of Nebraska-Lincoln, amandalgarrett@gmail.com \\ Ellen Weissinger \\ University of Nebraska-Lincoln, eweissinger1@unl.edu \\ Namas Chandra \\ University of Nebraska-Lincoln, nchandra2@unl.edu
}

Follow this and additional works at: https://digitalcommons.unl.edu/mechengfacpub

Part of the Mechanical Engineering Commons

Howell Smith, Michelle C.; Garrett, Amanda L.; Weissinger, Ellen; and Chandra, Namas, "It's Not What You Think: A Theory for Understanding the Lack of Interest among Domestic Students in the Engineering PhD" (2011). Mechanical \& Materials Engineering Faculty Publications. 72.

https://digitalcommons.unl.edu/mechengfacpub/72

This Article is brought to you for free and open access by the Mechanical \& Materials Engineering, Department of at DigitalCommons@University of Nebraska - Lincoln. It has been accepted for inclusion in Mechanical \& Materials Engineering Faculty Publications by an authorized administrator of DigitalCommons@University of Nebraska Lincoln. 


\title{
It's Not What You Think: A Theory for Understanding the Lack of Interest among Domestic Students in the Engineering PhD
}

\author{
Michelle C. Howell Smith, Amanda L. Garrett, Ellen Weissinger, Namas Chandra \\ University of Nebraska-Lincoln \\ mhowel12@unl.edu, amandalgarrett@gmail.com, eweissinger1@unl.edu,nchandra2@unl.edu
}

\begin{abstract}
We live in a fast-paced world surrounded by technological advances. Engineers with advanced skills perform important functions in our society. However we know very little about how engineers consider obtaining advanced education and skills. The purpose of this study is to understand and develop a theory explaining the process domestic engineers undergo in developing an interest in obtaining a $\mathbf{P h D}$ in engineering. Our research was guided by the following central research question: What is the theory that explains the process of developing interest in doctoral-level engineering education for engineers? We used qualitative, grounded theory methods, to investigate the process of advanced engineering education interest. Interview data were collected from undergraduate engineering students, doctoral engineering students, engineering faculty, and engineers in industry with $\mathrm{PhD}$ degrees from seven institutional sites. Our theory explains that misperceptions, personal characteristics, and environmental elements are part of engineers' interest in advanced education. Engineers must be exposed to these factors and must also actively process this information to develop interest. This theory provides a framework for understanding and promoting doctoral education for engineers. Implications for educators are offered.
\end{abstract}

Index Terms - Domestic Students, Engineering PhDs, Qualitative Research.

\section{INTRODUCTION}

As the challenges facing engineers become larger and more complex, so does the need for increased sophistication and innovation to address these challenges. The $\mathrm{PhD}$ in engineering provides an opportunity to develop engineers with the advanced knowledge and innovative skills to meet these new and ever-changing demands and to ensure "our country's future economic prosperity, influence social growth, and maintain our leadership in the global economy" [1]. The National Academy of Sciences [2] expressed concern regarding the looming shortage of scientists and engineers, describing it as a "Gathering Storm." The status of this storm was recently upgraded to a "Category 5" as a warning and a reminder that "rebuilding from such an event is far more difficult than preparing in advance to withstand it" [3]. It was a clear call to action to train more advanced scientists and engineers.

The $\mathrm{PhD}$ has traditionally been perceived as an apprenticeship period to prepare future faculty of our nation's colleges and universities and with the impending retirement of a substantial number of baby-boomer faculty, there will be increased opportunities for $\mathrm{PhDs}$ to obtain faculty positions [4]-[9]. In engineering, however, only 15$30 \%$ of $\mathrm{PhDs}$ obtain an academic position, while the remaining $70-85 \%$ of engineering $\mathrm{PhDs}$ obtain positions in non-academic settings [10]-[12].

Our knowledge about interest in doctoral education is deficient as the engineering education literature predominantly focuses on the undergraduate engineering experience. While those in the engineering field may have many of their own anecdotal explanations of the reasons domestic engineering students do not persist through the doctoral level, the existing literature has not focused on the process of how engineers come to cultivate their interest in doctoral-level engineering education, and how they turn this interest into action and pursue such a degree. Researchers have not explored this area thoroughly and have not used rigorous qualitative methods, such as grounded theory, to develop a model detailing this process. The question remains: Why are so few domestic undergraduate engineering students interested in pursuing a $\mathrm{PhD}$ ? Such empirical knowledge is a necessary prerequisite to designing valid strategies to increase domestic $\mathrm{PhD}$ enrollments.

\section{Purpose Statement}

The purpose of this qualitative grounded theory study was to identify the factors that facilitate and inhibit interest in engineering $\mathrm{PhD}$ programs among domestic engineering undergraduate students. This study contributes new lines of inquiry to the literature of engineering education by researching and analyzing the experiences of undergraduate engineering majors, engineering $\mathrm{PhD}$ students, engineering faculty, and industry professionals who have earned a $\mathrm{PhD}$ in engineering. This analysis led to the development of a theory that describes the process of increasing interest in the engineering $\mathrm{PhD}$. By presenting a complete and accurate understanding of the factors that underlie the decision to pursue or forego an engineering $\mathrm{PhD}$, engineering programs 
will be able to develop and prioritize new strategies for increasing domestic $\mathrm{PhD}$ enrollments.

\section{Research Questions}

1. What perceptions do domestic engineering students, engineering faculty members and other engineering PhDs hold about $\mathrm{PhD}$ education in engineering?

2. What factors inhibit or facilitate interest in the engineering $\mathrm{PhD}$ among domestic engineering students?

\section{METHODS}

\section{Grounded Theory Approach}

Grounded theory methodology is a popular qualitative inquiry approach that is used to build theory through a "systematic, inductive, and comparative" process [13]. The intent of the grounded theory research process is to produce strong substantive or formal theories where none existed previously [14]-[16]. A grounded theory approach was selected for this study because the aim of this project is to generate a theory about the process of developing interest in $\mathrm{PhD}$ programs for engineers. Grounded theory methods allowed us to examine the statements of engineers, engineering students and faculty to produce a theoretical explanation solidly grounded in the data from these participants and to transcend a simple listing of the facilitating and inhibiting factors of attaining a $\mathrm{PhD}$ degree in engineering. "Generating theories about a phenomena, rather than just generating a set of findings, is important to the development of a field of knowledge" [17]. The research team wanted to craft a theory as well as actionable steps to impact the number of engineers who earn doctoral degrees. "A theory does more than provide understanding or paint a vivid picture. It enables users to explain and predict events, thereby providing guides to action" [17].

\section{Participating Institutions}

Seven institutions agreed to participate in this study as data collection sites. Data collection occurred over the course of the 2009-2010 academic year. Characteristics from the data collection sites are summarized in Table I.

\section{Focus Groups}

Two focus groups, with attendance ranging from $8-12$ undergraduate students, were held at each site for a total of 14 focus groups. Participation in the focus groups was limited to domestic junior and senior engineering majors with a minimum 3.0 GPA. A "purposefully random" sampling strategy was used so that participants were representative of their particular campus. Women and underrepresented minorities were over sampled to ensure that their perspectives were included. Focus groups were 60 minutes in length, including time for eating pizza and conducting introductions.

\section{Individual Interviews}

Individual interviews were held with a variety of engineers who had either earned or were pursuing a $\mathrm{PhD}$ in engineering. Engineering faculty were identified by publicly available information on institutional Web sites at each participating site and were selected to represent a balance of departments and academic ranks. Engineering PhD students were also identified via publicly available information on institutional Web sites and personal contacts. Since only 3 of the sites offered a $\mathrm{PhD}$ in engineering, additional phone interviews were conducted. Students were selected to represent a diversity of majors. Individuals with engineering PhDs who work in industry were recruited via personal contacts and networking. In total, there were 32 faculty interviews, $16 \mathrm{PhD}$ student interviews and 6 industry $\mathrm{PhD}$ interviews. Individual interviews were $15-30$ minutes in length.

TABLE I: CHARACTERISTICS OF PARTICIPATING DATA COLLECTION SITES

\begin{tabular}{|c|c|c|c|c|}
\hline $\begin{array}{l}\text { Apx. Student } \\
\text { Body Size }\end{array}$ & $\begin{array}{l}\text { Geograp hic } \\
\text { Area }\end{array}$ & $\begin{array}{l}\text { Public/ } \\
\text { Private }\end{array}$ & $\begin{array}{l}\text { Engineering } \\
\text { Ranking * }\end{array}$ & Characteristics \\
\hline 2,000 & Mid-West & Public & Notranked & Engineering focused \\
\hline 2,000 & Mid-West & Private & Top 10 & Engineering focused \\
\hline 2,500 & Mid-West & Private & Top 20 & $\begin{array}{l}\text { Engineering focused } \\
\text { Special co-op program s }\end{array}$ \\
\hline 30,000 & South-West & Public & Notranked & $\begin{array}{l}\text { Very high research activity } \\
\text { Hispanic Serving Institution(HSI) }\end{array}$ \\
\hline 20,000 & West Coast & Public & Top 20 & $\begin{array}{l}\text { Master'slevel gaduate program s } \\
\text { Hispanic Serving Institution(HSI) } \\
\text { Special diversity program s }\end{array}$ \\
\hline 30,000 & Mid-West & Public & Top 50 & Very high research activity \\
\hline 25,000 & Mid-West & Public & Top 100 & Very high research activity \\
\hline
\end{tabular}

$*[18]$

\section{Data Analysis}

Transcripts from the focus groups and individual interviews were loaded into MAXQDA 10, a qualitative data analysis software package. The software provided a vehicle for organizing the data and retrieving particular data segments for comparison or additional analysis efficiently. The data analysis followed the format outlined by Charmaz [19], consisting of a initial phase of coding words, lines or segments with meaningful labels followed by a selective phase where the initial codes are organized and integrated into a theoretical model. The research team used a constant comparative method of data analysis, meeting frequently throughout the coding process to continue to refine code lists and the evolving model. Memos were created to clarify the meaning of the codes and facilitate refining the analysis using the codes. 


\section{Data Validation}

Several validation strategies were employed by the researchers of this study to ensure the findings were an accurate representation of the participants' lived experience: member checking, triangulation among data sources and investigators, rich description, and discussion of researcher biases [20]-[21].

\section{Ethical Concerns}

In order to protect the rights of all participants, each participant signed an informed consent form as approved by the IRB. The backgrounds of the participants were reported in aggregate, describing the group as a whole, rather than describing each individual in order to protect their identity.

\section{Findings: Engineering Doctorate Pathway Model}

Each piece of the model will be discussed in turn. You may find it helpful to refer to Figure I before reading the findings. There were four major themes that emerged as a result of our analyses: pathways, personal characteristics, misperceptions, and environment.

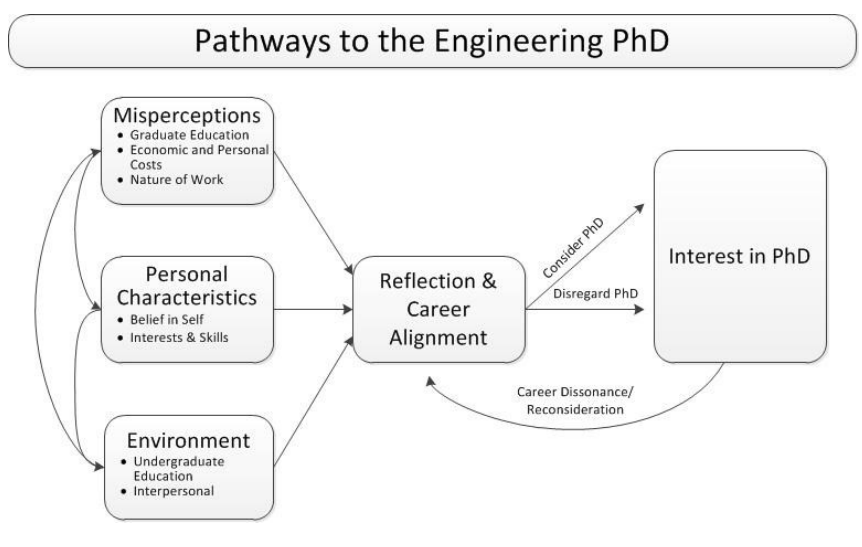

Figure I: Pathways to Interest in the Engineering PhD

Pathways

Overall, what we learned from the qualitative grounded theory analysis was that there is no one clear, linear pathway that leads to an engineering $\mathrm{PhD}$. Engineers can and do take many different routes to arrive at the destination of the engineering doctorate degree. Engineers can and do take many different paths to arrive at the destination of the engineering doctorate degree. We did identify general phases that engineers underwent on their path to the engineering $\mathrm{PhD}$ degree: influential factors, reflection process, and educational interest outcome. First, we found several factors that are pivotal in process for considering advanced education: misperceptions, environment, and personal characteristics. These factors heavily influenced each other and created a unique set of information for each engineer. Second, engineers in our study reflected on this combination of influences to arrive at their personal decision, based on their value system, to pursue the engineering $\mathrm{PhD}$. It is difficult for undergraduate students to understand how to plan their pathway to the $\mathrm{PhD}$ because the pathway involves a complex appraisal of a combination of factors and even unexpected events. Engineers who have earned PhDs could look back on their collective experiences and retrace the path that led them to an advanced educational track. Bachelor's-level engineers do not have a clear path forward to work towards a $\mathrm{PhD}$ because their goals are either unclear or center on obtaining a job after graduation. Finally, engineers arrive at their level of interest in pursuing a doctorate degree in engineering by progressing along the pathway. Engineers may actively consider many of the factors and demonstrate interest. Alternately, engineers may not fully contemplate the factors or have limited information and choose not to seek additional education. It is also possible that engineers may reenter the model and reconsider their educational future.

\section{Personal Characteristics}

Individuals bring their own set of skills, interests and abilities to their desire to be an engineer. Many people are drawn to engineering because they are good at math and science or they like building things with their hands or they enjoy problem solving. Most undergraduate engineering students enter college with the end goal of a bachelor's degree. Students who have a family member with a $\mathrm{PhD}$, regardless of discipline, are often an exception to this predisposition, as they are more likely to be open to considering a $\mathrm{PhD}$. Personal characteristics such as a deep curiosity and a love of learning may predispose an individual to be interested in pursuing a PhD. Confidence (or lack thereof) in their academic abilities also contributes to their level of interest in the $\mathrm{PhD}$. Many undergraduates are intimidated by the dissertation and question whether they are "smart enough" to earn a PhD.

\section{Misperceptions}

One of the primary findings of this study was the prevalence of the misperceptions undergraduate students have about the engineering $\mathrm{PhD}$. These misperceptions were found in every focus group discussion, regardless of institutional type or location. Because these misperceptions are believed to be true by most undergraduate students, they serve as a major barrier to the $\mathrm{PhD}$. We have categorized them into three primary groups: graduate education, economic and personal costs, and nature of work.

Graduate Education Misperceptions: Almost universally we found that undergraduate engineering students had a lack of information, or even outright misinformation regarding the pathway to engineering $\mathrm{PhD}$ programs. These misperceptions included how you get into graduate school, the cost of graduate school, and the workload of the doctoral curriculum. It was clear these 
misperceptions are a major barrier to interest in pursuing a $\mathrm{PhD}$ in engineering.

Economic and Personal Costs Misperceptions: It is true that money plays a part in the decision to pursue a $\mathrm{PhD}$ in engineering, but not in the way most people would assume. Undergraduate students expressed concern over paying off their undergraduate debt and not being able to afford to pay for graduate school. They seemed to be aware that many employers pay for a master's degree, but were not familiar with the traditional forms of support for graduate education from the program, such as teaching and research assistantships. They have worked hard through their undergraduate program and perceive continued education as deferring the rewards (high paying job, finer things in life) they have worked so hard to obtain.

Nature of Work Misperceptions: Misperceptions about the nature and type of tasks engineers with different levels of education would perform were prevalent in the data. Undergraduate engineers believe that they "can do anything" with their degree. They know they are a valuable commodity in the workplace and see no need for additional education, especially since they don't understand what it is $\mathrm{PhD}$ level engineers do. For the most part, the only $\mathrm{PhD}$ engineers they know are faculty, although approximately $80 \%$ of people who earn a $\mathrm{PhD}$ in engineering work in industry not academia [11]. Bachelors-level engineers do not perceive $\mathrm{PhD}$ engineers as "real" engineers and question why a company would hire an engineer with a $\mathrm{PhD}$ when a bachelor's degree employee could do the same work for less money. Undergraduates also perceive that the specialization of a $\mathrm{PhD}$ would limit them in the job market.

\section{Environment}

The environment and the people in the environment are key elements in how engineers make a decision about advanced engineering education. Both the events in the undergraduate experience and those individuals in which they came in close contact with are important elements of their educational pathway.

Undergraduate Education Environment: The curriculum and workload of undergraduate engineering programs seems to cause a lot of burnout among engineering students. This burnout is a barrier to pursuing an advanced degree in engineering because most undergraduates are ready to "have a life." Further, they project the undergraduate workload and curriculum onto graduate programs and do not understand the fundamental differences in graduate education. The educational environment can directly impact interest in the $\mathrm{PhD}$ by providing programs and services that encourage doctoral education. Programs such as McNair, LSAMP and REUs provide an opportunity for students to learn more about doctoral education and gain experience in conducting research. This direct experience helps to counteract many of the misperceptions that serve as barriers to the $\mathrm{PhD}$.
Interpersonal Environment: The influence of others (family, peers, colleagues and faculty) plays an important role influencing an individual's interest in pursuing an engineering $\mathrm{PhD}$. Influence ranges from active discouragement to passive silence to active encouragement. When others discourage the $\mathrm{PhD}$, it reinforces the lack of interest. However, when important others encourage the $\mathrm{PhD}$, it can increase the interest level.

\section{Career Alignment and Reflection}

Engineers draw from their information and experiences to decide if they will make a decision on whether or not to pursue graduate engineering education. The reflection process is the pivotal place in the model where the individuals' personal characteristics, beliefs, and environment intersect. It is in this place that these elements combine to encourage or discourage interest in the engineering $\mathrm{PhD}$. Each individual engineer assigns different values or coefficients to the factors with his own personal value system to critically evaluate the benefits and costs associated with advanced education. Through the individual's actions and interaction with others, the educational and career trajectory is determined. High levels of exposure and active engagement lead to a consideration of or interest in the $\mathrm{PhD}$; whereas low levels of exposure and engagement result in maintaining a lack of consideration of or interest in earning a $\mathrm{PhD}$ in engineering. Experiences and interactions that occur before undergraduates have deeply committed to a career path towards a high paying job can be very beneficial. However, later interventions can also be successful in fostering interest in the PhD. Maturity also plays a role, and the college environment is rich with opportunities to help students develop their identity. These experiences clarify and deepen career goals and may increase their interest in the PhD. In many cases, a period of time for reflection is needed for the student to process his or her experiences and begin to consider the $\mathrm{PhD}$ as a potential career path.

\section{Engineering Interest}

We learned that the default setting for most undergraduate engineers is a lack of consideration of, interest in, or a plan for pursuing the $\mathrm{PhD}$ in engineering. The pressure to get a high-paying job and the desire to "have a life" where the workload is not as intense as the undergraduate curriculum reinforces this lack of interest. However, what we learned from people who were pursuing or had already earned a $\mathrm{PhD}$ in engineering was that their pathway to the PhD contained unexpected, unplanned experiences, that most often seem inconsequential at the time, but that changed the trajectory of their career path. These moments, in hindsight, were salient and pivotal in shaping their decision to pursue the $\mathrm{PhD}$. The nature of these moments varied for each participant. The commonality among the stories is that there was an accumulation of these moments that ultimately 
tipped the scales in the direction of the PhD. Engineers may have a delayed decision to pursue advanced education. Thus, it is possible for engineers to reenter the model and actively reconsider their interest in the $\mathrm{PhD}$.

\section{DISCUSSION}

Many scholars have referred to the attrition of students, particularly underrepresented minorities and women, from STEM programs as a "leaky pipe" where at each stage of educational attainment students leak out of the pipeline [22][26]. Manderscheid [27] referred to it as a "burst pipe" causing significantly more damage than a mere leak. While the pipeline metaphor has been effective in stimulating interventions to increase diversity in science and engineering fields, it oversimplifies the complex interactions of identity, cognitive development and career choice [28]. Responding to a call to retire the leaky pipeline metaphor [29], several studies have advanced an alternate view of enrollment trends in doctoral STEM programs: "The route to graduate education should be thought of as a pathway rather than a pipeline. A pipeline implies a system in which a student enters at one end and comes out at the other. There is only one entry point, and once a student leaves the pipeline there is no way back in. A pathway, however, suggests a less linear approach in which a student may meander at times, but where leaving the main path does not mean that is will be impossible to reenter it later" [1]. Other studies also embraced this new concept [29]-[30].

The pathway metaphor also served as a framework for a longitudinal study funded by the National Science Foundation conducted by the Center for the Advancement of Engineering Education [31]-[32]. The Academic Pathways of People Learning Engineering Survey (APPLES) recognized that a "broad understanding of the engineering student experience involves thinking about diverse academic pathways, navigation of these pathways, and decision pointshow students choose engineering programs, navigate through their programs, and then move on to jobs and careers" [31]. The pathway metaphor also acknowledged that "engineering is increasingly viewed as a flexible platform for a variety of career options; a singular career trajectory is increasingly uncommon given today's professional and economic realities" [32]. In addition to conceptualizing the multiple pathways through undergraduate engineering education, the study also noted that "supporting less-traveled pathways has the potential for broadening participation in engineering" [31].

Our findings certainly compliment the work of the APPLES study by extending their concepts into doctoral level education. Although the pathway to the engineering $\mathrm{PhD}$ is often obscured by misperceptions and environmental cues, there exists a great opportunity for helping students explore the realities of the $\mathrm{PhD}$ pathways so that they may accurately assess the relevance and utility of the $\mathrm{PhD}$ for their own personal interests and goals.

\section{RECOMMENDATIONS FOR EDUCATORS}

The opportunities for educators to intervene and foster engineers' interest in the engineering $\mathrm{PhD}$ are many. We have categorized these strategies into those that can be implemented by undergraduate programs and by graduate programs. We realize that engineering faculty serve both programs concurrently, but wanted to make special note of the unique role each perspective has to play in addressing the issues.

\section{Recommendations for Undergraduate Programs}

Faculty in undergraduate engineering programs can provide more information on doctoral education in engineering to their students. Exposure to the $\mathrm{PhD}$, through such experiences as graduate school workshops or even lab tours, gives students ideas that they can build upon. Additional examples of exposure could include interactions those who are earning or who have earned $\mathrm{PhD}$ degrees, such as current PhD students and industry engineers with PhDs. Promoting engineering role models, especially those who would work with students over the long-term to provide mentoring, are recommended. Showing engineers the breadth of engineering careers available to them with varying levels of education is also important as many engineers do not realize the advanced education that may be required for certain positions. Encouraging undergraduate research and internships provide engineers with importance experiences and contacts to build on. Promoting masters education is another positive step that may provide more accurate knowledge of the doctoral education experience.

\section{Recommendations for Graduate Programs}

Graduate Programs also have a role to play in increasing interest in $\mathrm{PhD}$ programs among domestic students. Graduate programs need to educate prospective students about the lifestyle of graduate students. Developing schedules that are conducive to full-time working adults and that allow for a work/life balance were suggested by several participants. Additionally, graduate programs may need to expand their recruitment efforts beyond the captive audience of current undergraduate students and reach out to recent alumni. A period of work experience (often described as mundane or boring) was typical for many people who had earned or were pursuing their $\mathrm{PhD}$. Finally, graduate programs need to recognize that most undergraduates have not developed the self confidence to feel they could be successful in a doctoral program. Participating in a master's degree program is an opportunity for them to experience graduate school, have success with the graduate curriculum and begin to see the $\mathrm{PhD}$ as something obtainable. 


\section{CONCLUSIONS}

While this study confirms much of what was already known or assumed to be known about undergraduate student interest in the engineering $\mathrm{PhD}$, it did yield one very significant finding: Undergraduate students have no idea what the PhD is really about or why anyone would need one, unless they wanted to become a professor. The educational environment does little to correct these misperceptions and encourages students to focus instead on the big payoff for all of their hard work - an interesting job with a high salary and leisure time to be able to enjoy it. The good news is, that there are simple, inexpensive and concise actions that engineering educators can implement that can challenge those misperceptions about the engineering $\mathrm{PhD}$ and open up a career path to a group of students who otherwise would likely not have considered it.

\section{REFERENCES}

[1] Wendler, C., Bridgeman, B., Cline, F., Millett, C., Rock, J., Bell, N., \& McAllister, P., The path forward: The future of graduate education in the United States, 2010.

[2] National Academy of Sciences, Committee on Prospering in the Global Economy of the $21^{\text {st }}$ Century, Rising above the gathering storm: Energizing and employing America for a brighter economic future, 2007.

[3] National Academy of Sciences, Rising Above the Gathering Storm Committee, Rising above the gathering storm, revisited: Rapidly approaching category 5, 2010

[4] Austin, A. E., "Preparing the next generation of faculty: Graduate school as socialization to the academic career", The Journal of Higher Education, 73, 2002, 94-122

[5] Campbell, R. A., "Preparing the next generation of scientists: The social process of managing students.", Social Studies of Science, 33, 2003, 897-927.

[6] Campbell, S. P., Fuller, A. K., \& Patrick, D. A., "Looking beyond research in doctoral education", Frontiers in Ecology and the Environment, 3, 2005, 153-160.

[7] Golde, C. M. \& Dore, T. M., At cross purposes: What the experiences of today's graduate students reveal about doctoral education, 2001.

[8] Lederman, D., "A haven for minority scholars", Inside Higher Ed, October 30, 2007.

[9] Louis, K. S., Holdsworth, J. M., Anderson, M. S. \& Campbell, E. G., "Becoming a scientist: The effects of work-group size and organizational climate", The Journal of Higher Education, 78, 2007, 311-336.

[10] Fox, M. F. \& Stephan, P. E., "Careers of Young Scientists: Preferences, prospects and realities by gender and field", Social Studies of Science, 31, 2001, 109-122.

[11] Mason, M. A., Goulden, M. \& Frasch, K., "Why graduate students reject the fast track." Proceedings of the American Association of University Professor,. Academe, 95(1), 2009, 11-16.

[12] National Science Foundation, Division of Science Resources Statistics, Doctorate Recipients from U.S. Universities: 2009 (NSF 11-306), 2010.

[13] Bryant, A. \& Charmaz, K., "Grounded theory research: Methods and practices", In A. Bryant and K. Charmaz (Eds.), The sage handbook of grounded theory, 2007, 1-28.

[14] Glaser, B. G., "Doing formal theory", In A. Bryant and K. Charmaz (Eds.), The sage handbook of grounded theory, 2007, 97-113.

[15] Glaser, B. G., \& Strauss, A. L., The discovery of grounded theory: Strategies for qualitative research, 1967.

[16] Kearney, M. H., "From the sublime to the meticulous: The continuing evolution of grounded formal theory, In A. Bryant and K. Charmaz (Eds.), The sage handbook of grounded theory, 2007, 127-150.
[17] Strauss, A. \& Corbin, J., Basics of qualitative research: Techniques and procedures for developing grounded theory, 1998.

[18] U.S. News and World Report, "Best engineering schools", 2011.

[19] Charmaz, K., Constructing grounded theory: A practical guide through qualitative analysis, 2006.

[20] Creswell, J. W., Qualitative inquiry and research design: Choosing among five traditions, 2007.

[21] Creswell, J. W., \& Miller, D. L., "Determining validity in qualitative inquiry", Theory Into Practice 39, 2000, 124-130.

[22] Atkin, A. M., Green, R., \& McLaughlin, L. "Patching the leaky pipeline", Journal of College Science Teaching, 32, 2002, 102-108.

[23] Durant, E., "Plugging the leaky pipeline: Science and engineering industries drain women from academe, but MIT is trying to reverse the flow", MIT Technology Review, 2004.

[26] Wickware, P., "Along the leaky pipeline", Nature, 390, 1997, 202203.

[27] Manderscheid, D., "Increasing the number of minority PhDs", University of Nebraska-Lincoln Interdisciplinary Faculty Retreat: Recruiting and Retaining Diverse Students, 2007.

[28] Watson, K. \& Froyd, J., "Diversifying the U.S. engineering workforce: A new model", Journal of Engineering Education, 96(1), 2007, 19-32.

[29] Stevens, R., O’Connor, K., Garrison, L., Jocuns, A., \& Amos, D., "Becoming an engineer: Toward a three dimensional view of engineering learning", Journal of Engineering Education, 97(3), 2008, 355-368.

[30] Fouad, N. A. \& Singh, R., Stemming the tide: Why women leave engineering, 2011.

[31] Atman, C. J., Sheppard, S. D., Turns, J., Adams, R. S., Fleming, L. N., Stevens, R., Streveler, R. A., Smith, K. A., Miller, R. L., Leifer, L. J., Yasuhara, K., \& Lund, D. Enabling Engineering Student Success: The Final Report for the Center for the Advancement of Engineering Education (TR-10-02), 2010.

[32] Sheppard, S., Gilmartin, S., Chen, H. L., Donaldson, K., Lichtenstein, G., Eris, O., Lande, M., \& Toye, G., Exploring the engineering student experience: Findings from the academic pathways of people learning engineering survey (APPLES) (TR-10-01), 2010

\section{ACKNOWLEDGEMENTS}

This material is based upon work supported by National Science Foundation award EEC-0935108; The opinions, views, and conclusions expressed in this article may not reflect those of the funding agency. Additional details about this study may be found in Howell Smith, M. C., "Factors that facilitate or inhibit enrollment of domestic engineering PhD students: A mixed methods study", University of Nebraska-Lincoln Dissertation, 2011.

\section{AUTHOR INFORMATION}

Michelle C. Howell Smith, Doctoral Candidate, Educational Psychology, University of Nebraska-Lincoln, mhowell2@unl.edu.

Amanda L. Garrett, Doctoral Student, Educational Psychology, University of Nebraska-Lincoln, amandalgarrett@gmail.com.

Ellen Weissinger, Ph.D., Senior Vice Chancellor for Academic Affairs and Professor of Educational Psychology, University of Nebraska-Lincoln, eweissinger1@unl.edu.

Namas Chandra, Ph.D., Elmer E. Koch Professor of Engineering Mechanics and Associate Dean for Research of the College of Engineering, University of Nebraska-Lincoln, nchandra2@unl.edu 